\title{
Strategy of Social Fund Distribution in ACT-MRI Parepare
}

\author{
Muhammad Majdy Amiruddin, Islamul Haq, Nur Alviana Nasir, Nurhasana \\ IAIN Parepare \\ Jl. Amal Bhakti No.8, Bukit Harapan, Kec. Soreang, Parepare, Sulawesi Selatan \\ Email: muhammadmahdyamiruddin@iainpare.ac.id
}

Diterima: 3 Juni 2020; Direvisi: 29 Juni 2020; Diterbitkan: 10 Juli 2020

\begin{abstract}
Abstrak,
Penelitian ini bertujuan untuk untuk menganalisis strategi alokasi dana filantropi yang diterapkan oleh Aksi Cepat Tanggap bersama Masyarakat Relawan Indonesia (ACT-MRI) kota Parepare. Pendekatan dalam penelitian ini adalah pendekatan kualitatif dengan desain penelitian studi kasus. Hasil penelitian menunjukkan bahwa dana filantropi yang telah dikumpulkan oleh MRI Kota Parepare akan didistribusikan ke dalam empat program utama, program intens, santunan kaum dhuafa sistem MSR (Mobile System Resecue), bantuan berupa barang yang dirupiahkan, Pengantaran Langsung Bantuandana kepada penerima bantuan. Strategi distrubusi menganut sistem diversifikasi. Penelitian ini diharapkan menjadi acuan kepada para pengurus dan volunteer agar meningkatkan kerja sama dengan pemerintah dan lembaga pendidikan. Kerja sama dengan pemerintah diperlukan agar program intense dan MSR bisa berjalan lebih optimal tanpa ada tumpang tindih kepentingan. Lembaga pendidikan bisa memberikan kontribusi berupa tenaga volunteer sehingga sumber daya menusia bisa terjamin
\end{abstract}

Kata Kunci: ACT, Alokasi, Filantrofi, MRI, Strategi, diversifikasi

\begin{abstract}
,
This study aims to analyze the philanthropic fund allocation strategy implemented by the Aksi Cepat Tanggap collaborated with Masyarakat Relawan Indonesia (ACT-MRI) of Parepare. The approach in this research is a qualitative approach with a case study research design. The results showed that philanthropic funds collected by MRI of Parepare City would be distributed into four main programs, intense programs, compensation for the poor of the MSR system (Mobile System Resecue), assistance in the form of goods to money, Direct Delivery of aid funds to recipients. The distribution adapted diversivication strategy. This research is expected to be a reference to the management and volunteers to improve cooperation with the government and educational institutions. Cooperation with the government is needed so that the intense program and MSR can run more optimally without overlapping interests. Educational institutions can make a contribution in the form of volunteers so that human resources can be guaranteed
\end{abstract}

Keywords: ACT, Allocation, Philanthropy, MRI, Strategy, Diversification 


\section{INTRODUCTION}

Philanthropy in general meaning is familiar known as an act of someone who is grounded in the love of others (humans) so that it encourages him to donate or sacrifice something in the form of time, money, or energy to help others. As social beings, humans need each other. From this perpective, many social activities are carried out in the community, plus institutions and social communities that surfaced, thereby increasing the list of social activities and movements that could be the people's choice to contribute (Fauzia, 2018).

The emergence of a humanitarian agency initiated by the Aksi Cepat Tanggap (ACT) in 2004 during the Aceh tsunami tragedy at that time. Rapid response was formed at the initiative of volunteers who at that time many casualties fell, but volunteers who are about disaster locations are increasingly reduced. It was only in 2005 that ACT carried out its program of activities on the basis of humanity to form the Masyarakat Relawan Indonesia (MRI). MRI can be called as a forum formed by ACT to coordinate human resources who have various competencies in the community. Until now MRI's work has been proven from various concrete actions that have been carried out over the last few years. Synergizing with many parties, MRI was able to create a program for channeling funds in various opportunities both disaster relief and assistance in the form of compensation (Rahmadi \& Syauqillah, 2019).

The formulation of the problem outlined above and to clarify the direction of the research, the main problem is how the philanthropic fund allocation strategy is implemented by the Rapid Action Response with the Indonesian Volunteer Community (ACT-MRI) of the city of Parepare. This study aims to analyze the philanthropic fund allocation strategy implemented by the Rapid Action Response with the Indonesian Volunteer Community (ACTMRI) of the city of Parepare. This research is limited to one of the ACT activities programs namely the Mare Parepare branch in the management of philanthropic funds, namely the strategic allocation made by MRI volunteers to assist in providing financial assistance to victims of natural disasters and providing assistance to the poor (Hadi, n.d.).

\section{LITERATURE REVIEW}

Islamic philanthropy in history has actually appeared since the 15th century ago, Muslims knew it in various popular designations such as endowments, alms and grants. Philanthropy in Islam according to Robert McChesney is a moral obligation of those who believe to do good deeds in the name of God (Fauzia, 2018).

Philanthropy is then better known in its general meaning as an act of someone who is grounded in a sense of mutual love (human) so that it encourages him to donate or sacrifice something in the form of time, money, or energy to help others. Islam teaches its people 
especially the rich, to care for the poor or those who have excess property to give part of their wealth to those who are heavily in debt and those who are deficient is a mandate in a noble religion. These charitable efforts or activities are called Islamic philanthropy. In the encouragement of giving contained the ideal values of generosity, social justice, and sharing and mutually reinforcing among Muslims (Wahyuni, 2017).

Regarding the theory of allocation in the view of Islamic economics that is focused on the problem of allocating resources in the presence of government intervention so that the allocation of resources can be well distributed. Considering that economic resources are scarce, their allocation must benefit humans. In allocating funds there must be a strategy to be achieved so that organizational goals can be achieved (Amiruddin, 2019).

Generally, every person can not be separated from activities in the environment in which he is, so someone always dreams of how he is calm or superior in his environment. Therefore, every person is basically a strategic person, where he must face his competitors in the environment, with thoughts to achieve his goals or expectations. A person who is a strategic person, will always face the task or activity to identify opportunities to determine what will be done to achieve goals or expectations. Determination of what will be done is, in the context of achieving its objectives, often referred to as "strategy" (Assauri \& Assauri, 2011).

Many formulations of what is a strategy, one of which is related to the decision-making that must be taken in dealing with competitors in an interdependent environment of life, so that there has to be activities directed primarily in estimating the behavior of one another. The strategy determined, can be formulated as determining the goals and objectives of an organization that is fundamental for the long term. The determined strategy is the appointment of the formulation of a series of actions or actions, as well as the allocation of resources needed to achieve the stated goals and objectives. All of these formulations lead to strategic ideas and conception of strategy, which is a dream in making players or thinkers of strategic management (such as managers, consultants and academics), can identify patterns of existing ideas. Ideas like this are the strength of a business idea (Sofjan Assauri, 2013).

Thus, the term "strategy" is formulated as a goal to be achieved, an effort to communicate what will be done, by who does it, how to do it, and to whom these things are also communicated, and also needs to be understood why the results the performance needs to be assessed. A strategy consists of a collection of integrated vane choices, and it is important to realize that these choices may not necessarily reach or fulfill choices that are considered important from something faced by the leadership or executive. Clearly, "strategy" is a communication tool, in which strategic people must strive to be able to ensure that the right person can know what the goals and objectives of the organization, as well as how it is placed in the implementation of the action, or realized. Thus, the "strategy" is directed or addressed, 
how the organization seeks to exploit or strive to be able to influence its environment and choose internal organizing efforts, where the latter is not part of the strategy (Tjiptono, 2008).

From the description of what has been described above, it can be stated that "strategy" is a statement that directs how each individual can work together in an organization, in an effort to achieve the goals and objectives of the organization. With this emphasis on collaborative efforts, the "strategy" must be able to describe the right or appropriate direction of the decision, and this is important as the basis for achieving an organization's goals and objectives. In addition, the "strategy" must also be able to produce tangible resources, not only in the form of income or profits but also can be in the form of intangible or intangible resources, such as reputation, individual or employee commitment, brand identity, etc.

Finally, it needs to be realized that basically, the "strategy" carried out by an organization is a set of commitments for integrated and coordinated actions or actions, to seek or cultivate competence and at the same time to gain an organization's competitive advantage. The "strategy" carried out by the organization as described, is often associated with efforts to integrate and allocate resources, capabilities and competencies of the organization, in order to be successful in its ever-changing external environment (Sofjan Assauri, 2013).

In social fund management, there are two main strategies can be adapted, namely fundraising strategy and distribution strategy. Fundraising strategy refers to tools of analyses to recognize the potential source of fund, fundraising method, evaluate institution capacity to mobilize the fund. Distribution strategy refers to tools of analyses to recognize the potential fund allocation, distribution method and evaluate recipient development (Ridwan, 2016).

Most similar research analyses fundraising strategy made by institution. They focus on how to get more fund instead of how the fund can reach the recipient effectively. Many phyilantrophy institution seem to ignore the allocation of fund and how they distribute it. They don't seem to realize that loyal donors come from how we channel funds to the right parties. This research exposes distribution strategy that focuses on the distribution method conducted by MRI-ACT.

\section{METHODS}

The approach used is a qualitative, the qualitative approach emphasizes its analysis in the deductive and inductive inference process and analysis of the dynamics of the relationship between observed phenomena, using scientific logic (Syaifuddin Azwar, 2004). Design of research is a case study. case studies aim to intensively study the background, current status and environmental interactions that occur in social units such as individuals, groups, institutions or communities. The scope of case studies can cover the entire life cycle or can 
only cover certain segments, can be focused on a number of specific factors and can also pay attention to all elements.

Qualitative Approach and Case Study Type are intended to get a comprehensive and systematic picture related to the allocation of philanthropic funds for the provision of aid in the form of funds to victims of disasters and compensation for the poor by MRI Parepare Branch. It is expected that the results of the research can be known, how the MRI strategy in the allocation of philanthropic funds for the provision of assistance in the form of funds to disaster victims and the compensation of the poor and what problems are faced. Data sources in this study are divided into primary and secondary data. Primary data in this study are data directly obtained from informants based on interviews, informants in this study are people who are in the management structure of BMH Malang Branch, including: Sabri (Head of Education and Training Center) and MRI Membership of the Parepare Branch), and Lubis (Member of the Head of Education and Training Division and MRI Membership of the Parepare Branch). While the secondary data in this study are data related to research, data obtained from books, journals, internet and other sources.

To obtain the approporiate data relevant to the research, the study employs three data collection techniques, namely Observation, In-depth Interviews (depth interviews) and Documentation Studies.

Method of data analyses adapted descriptive qualitative analysis, namely by describing factual information obtained from MRI Parepare branch, which is related to the management of philanthropic funds ranging from collection to utilization of these funds for the benefit of the education of poor children, with the aim of making a description, a systematic, factual and accurate picture or painting of the facts, characteristics and phenomena studied (Moh. Nazir, 2003).

\section{DISCUSSION}

Narrated from Sabri, Member of ACT, "ACT was formed first in the momentum of the 2004 earthquake in Aceh. At the initiative of many volunteers who appeared but later seemed to disappear from the disaster site. So this location was abandoned from the help of volunteers, finally some people took the initiative to form an institution that could keep up with victims of natural disasters like this, finally they initiated the rapid response in 2004 in the tsunami earthquake momentum in Aceh" (Sabri, Personal Communication, 19 November 2019).

Through its program of activities ACT formed the Masyarakat Relawan Indonesia (MRI) on May 22, 2005 in Banjarmasin, South Kalimantan on the basis of social activities and movements that could be the people's choice to contribute, in other words MRI as a provider 
of human resources. The aroma of volunteerism after the tsunami in Aceh at the end of December 2004 greatly encouraged the formation of MRI, because volunteers gathered in Banjarmasin at that time were none other than the 'veterans' of the Aceh tsunami. In addition, it must also be acknowledged that the greatest forms of volunteer activity that have taken place in this country were also displayed at the time of the Aceh tsunami. It can be imagined, volunteers from various corners of this country even from abroad came to the westernmost regions of Indonesia without being ordered, without being asked, without hoping for rewards, even without knowing when humanitarian work would end (MRI, n.d.).

The establishment of MRI, of course, is intended to accommodate various forms of care that are displayed by volunteers with various backgrounds and their various expertise and concentration. It is hoped that MRI will be able to become a forum to encourage the readiness of all citizens, ranging from students, students, teachers, workers / laborers, professionals, fishermen, farmers, military and other professions.

Lubis (personal communcation, 19 November 2019), one of MRI member stated “ACT and MRI are different even though MRI is the result of initiation from ACT. The Indonesian Volunteer Society (MRI) is a place for recruiting and cadre of volunteers who will assist in humanitarian activities".

"ACT and MRI are actually different than ACT as a school, while MRI is a volunteer or a school, each of which has a structural structure. However, ACT and MRI cannot be separated, in Parepare it was officially formed in 2018 around the end of the 11th month which was initiated by Fikruzzaman Saleh which started from coffee shop gathering friends who want to join in MRI volunteers. About dozens of people were moved to join the inauguration of the first MRI Parepare or its first orientation in 2019 in the first month of the nursing home as well as its inauguration".

This is one of the efforts of provincial level regional administrators. He targets around 50 thousand volunteers throughout South Sulawesi. He starts to form regional coordinator boards throughout South Sulawesi and then conducts an orientation roadshow for each regency / city throughout South Sulawesi.

a. Funding

The Indonesian Volunteer Society (MRI) was formed from the initiation of the Fast Action Response (ACT) and therefore the source of Social funds obtained by the Indonesian Volunteer Society (MRI) came from several funding sources including :

1) ACT Capital

MRI volunteers can ask for central funding assistance if there is an urgent matter in the matter of social funding assistance. However, because ACT has a directed SOP (Standard Operational Procedure), volunteers are not necessarily given financial 
assistance, because the central government must see whether financial assistance is appropriate or not.

As Stated from Lubis (personal communcation, 19 November 2019) "Not different from headquarters, MRI-ACT Parepare Branch strict to obey the SOP. Voluntters remain volunteer"

2) Social Funding

Lubis (personal communcation, 19 November 2019) mentioned, "volunteers are main soldier in MRI. The collected fund mostly from their initiative. Many accidental fundraising made by them when disasterc comes up"

This funding source is the result of participation and initiative from volunteers to collect aid funds, both natural disaster relief and other assistance. Usually the volunteers will go directly to raise funds in the community by determining the social access point that is implemented. Funds collected on that day are counted and if the funds obtained are deemed insufficient then the volunteers will go back down in the community to do social access.

3) Collaboration with Government

The Indonesian Volunteer Community cooperates with the government in various social funding assistance. But the cooperation meant is that the government only acts as a partner of the MRI itself. In other words, without government assistance, volunteers can move on their own to find funding. There is no form of government cooperation, it is not that they do not want government assistance but the Indonesian Volunteer Society (MRI) movement is not in direct contact with the government even if it is in the form of informal permits for socialization.

"The Local government appearently are still lack of trust on any private instition morever our existance still aroud the day. Many commoners still not familiar with us," Said Lubis (personal communcation, 19 November 2019).

4) Loyal Stakeholder

This funding assistance is from donors who provide direct funding assistance, meaning that donors come directly to the branch office or MRI secretariat in the local city. This donation can be in the form of money or goods that are suitable for use which will then be rediscovered by volunteers. As for donors who provide indirect aid funds, these donors send a number of aid funds to the MRI bank account.

"Loyal stake holder will increase along with our contribution. Eventhough there many seniors on this market, we still believe people will remember us through our action," as Lubis (personal communcation, 19 November 2019) mentioned. 
From the above explanation it can be concluded that the source of funds obtained by MRI is not only from fundraising alone. But it comes from various sources including: financial assistance from ACT, partnerships with the government, and financial assistance from individual donors or from other organizations, both directly and indirectly.

\section{b. Fund Allocation}

Basically, the diversification strategy is one of the important strategies in increasing sales volume. According to Fandy Tjiptono the diversification strategy is an effort to find and develop new products or markets, or both, in order to pursue growth, increase sales, profitability, and flexibility (Tjiptono, 2008). MRI adapted this strategy in its fund allocation to attaract social fund through several program activities including:

1) Intense Program

Lubis (personal communcation, 19 November 2019) narrated, "Our Main program to allocate fund is the intense program. We assist the needy until he can maintain his economic base. The assistance will continiue gradually and will pass the other needy"

This program is a program that is implemented by MRI volunteers in providing relief funds for both disaster victims and in the form of compensation for the poor. This program is also called Soffing Cerrity, looking for any shop that wants to do alms from the sale of goods, whether in the form of food, products, etc. For example, one product sold will set aside $5 \%$ or 500 rupiah for ACT-MRI, in this case the profit for the shop owner is that the shop will be promoted along with the product, or volunteers will make a banner in front of the store, shop means beinfak etc. Assistance provided intensively to people in need. This assistance will continue for the next few months, meaning that the assistance provided is not entirely but gradually in accordance with the needs. This program is designed so that the assistance provided can gradually provide benefits in the future for disaster victims and beneficiaries of assistance from the underprivileged. Specifically beneficiaries of the underprivileged are given this ongoing assistance until they feel completely biased towards their daily needs. without financial assistance in the future

2) Mobile Sysetem Rescue

"As I mentioned before, volunteers are our main force. They will go track disaster location and perform check to the victims. This what we call mobile system rescue" as mentioned by Sabir (personal communcation, 19 November 2019).

The MSR (Mobile System Resecue) system is a selection system for beneficiaries for the underprivileged, volunteers will make a proper assessment or not 
to be assisted and assisted in the long run. Volunteers will go down directly to the location of residence of the recipient of compensation to be re-checked whether or not given proper assistance. By visiting the person concerned, the volunteers in the draft or power point (ppt) are then sent to the center which determines whether or not they need to be disbursed to the poor. From MRI volunteers themselves, they usually provide assistance in the form of basic food.

3) Collected Goods to Money Transformation

Narrated from Lubis (personal communcation, 19 November 2019), "MRI System Operational Procedure (SOP) is not permitted to provide used clothing, new clothing, when there is used clothing, volunteers will return the clothing to the Market for Wearable Clothing (PLP). By looking at the size of different people's bodies, volunteers will help in the form of goods or replaced with logistics or what is needed at the disaster site"

Although donations are opened online with a target maximum amount of money that has been determined. If the donation is considered to have reached the nominal target and the collection period, the volunteer will stop raising funds. However, if there are still donors who want to help with the funds but have passed the specified day or the nominal target of money, volunteers are happy to accept donations from donors. Because it is a mandate from donors because the future needs are uncertain.

If prospective donors provide assistance, but in the form of goods assistance. The donor may not give used items as a donation aid. MRI System Operational Procedure (SOP) is not permitted to provide used clothing, new clothing, when there is used clothing, volunteers will return the clothing to the Market for Wearable Clothing (PLP). By looking at the size of different people's bodies, volunteers will help in the form of goods or replaced with logistics or what is needed at the disaster site.

4) Delivery Direct

The volunteers to the victims of disaster relief and the housing of beneficiaries of the underprivileged they use the budget from the personal money of each member of the MRI volunteers who are then used to go to the disaster site or the residence of the recipient who wishes to be given compensation of the underprivileged.

"The MRI fund allocation actually depends, if the campaign from Kitabisa.com actually depends on the type of activity, for example like the grandfather's house in Lauleng, it is one of the ACT programs and its donors from the book of kuisaisaisa, the distribution of the donors in stages. Example: if there are funds that are disbursed in Kitabisa.com 200 million volunteers cannot take the money at once, this is like 
building an automatic house such as a Budget Plan (RAB)", as Lubis mentioned (personal communcation, 19 November 2019).

\section{c. Challenges Faced by MRI}

In every work program created by an organization, certain internal and external companies will face certain obstacles, as well as the discussion above, regarding the strategy of allocating social funds from the Indonesian Volunteer Community (MRI) sourced from donor funds and action activity funds. social.

Lubis (personal communcation, 19 November 2019) stated, "Obstacles are crucially absent, but the obstacles are found in the slow disbursement of funds because the organization must meet previous SOPs. Because the Indonesian Volunteer Society (MRI) is part of the Indonesian Volunteer Community Community (MRI). This community was formed from the initiation of social programs from the humanitarian organization Aksi Cepat Tanggap (ACT). MRI is also a forum formed by ACT to coordinate human resources who have diverse competencies in the community. MRI's actions have proven to be a variety of concrete actions that have been carried out over the last few years. Synergizing with many parties, MRI is able to create programs with good success and accountability in financial reporting and reporting in the media. In terms of independence, volunteers contribute actively at the expense of their time, wealth and enthusiasm in realizing successful social activities carried out by ACT".

Standard Operational Procedure (SOP) is a document containing work procedures that must be carried out chronologically and systematically in completing a particular work in order to obtain the most effective work. Therefore MRI must follow the SOP that has been regulated by ACT because MRI is an ACT activity program that is engaged in the field of volunteers or Human Resources providers. But first through recruitment and regeneration so that volunteers can work together in accordance with the desired vision and mission.

\section{d. Benefits Given by MRI}

1) Poorer Direct Help

Santuna recipients for the underprivileged will become more independent in the future because the assistance is provided in stages every month until the recipient of the compensation can meet their daily needs. Because during the granting of financial assistance, volunteers will guide the recipient of the compensation until it truly feels independent. 
2) Disaster Victim Direct Help

Needs of disaster relief recipients will be met in the form of basic foodstuffs, clean water, medicines, baby equipment needs, clothing, and others needed while in evacuation.

3) Various Assistance for the Needy

Not only donors and philanthropists, both individuals and from various corporations and institutions that channel their concerns. A form of caring that is no less important and has a tremendous impact in every moment of disaster is the role of volunteers. From emergency volunteers, including rescue, relief and medical, to post disaster relief volunteers for handling trauma. Even in the recovery phase the roles and functions of volunteers continue to play. That said, none of the disasters occurred without the participation of volunteers. And in fact, the role played is very significant, from upstream to downstream. Those who started humanitarian work in the emergency phase, and are still continuing in the recovery phase.

\section{CONCLUSION}

Based on the results of the research and analysis of the discussion the researchers can conclude as follows:

Aksi Cepat Tanggap (ACT) was formed first in the momentum of the earthquake in Aceh in 2004. Through its program activities ACT formed the Masyarakat Relawan Indonesia (MRI) on May 22, 2005 in Banjarmasin, South Kalimantan. Formed on the basis of social activities and movements that could be the people's choice to contribute, in other words MRI as a provider of human resources. ACT and MRI are different but have the same goal.

Strategy conduct by MRI-ACTT vary from intense program, Mobile Rescue System, Logistic to Money Transform and direct delivery. This strategy called as diversity startegy. The allocation of MRI funds actually depends on the type of activity program. From emergency volunteers, including rescue, relief and medical, to post disaster relief volunteers for handling trauma. Even in the recovery phase the roles and functions of volunteers continue to play. That said, none of the disasters occurred without the participation of volunteers. And in fact, the role played is very significant, from upstream to downstream. Those who started humanitarian work in the emergency phase, and are still continuing in the recovery phase.

We recommend the in distributing MRI funds, the pattern of government partnerships should be improved so that the government can help and more the government is more sensitive to the poor in the area. The government will be also simultaneously promoting or socializing MRI to ordinary people who want to join to become ACT-MRI volunteers. Besides, 
the surrounding educational institutions can be source of volunteer. ACT-MRI needs to enchance the bound to the government and educational institution.

\section{REFERENCES}

Amiruddin, M. M. (2019). SYAIBANI ECONOMIC THOUGHT ON AL-KASB. Rausyan Fikr: Jurnal Studi Ilmu Ushuluddin Dan Filsafat, 15(1), 85-111.

Assauri, S., \& Assauri, F. (2011). Strategic management: sustainable competitive advantages. Penerbit Lembaga Management, Fakultas Ekonomi, Universitas Indonesia.

Fauzia, A. (2018). Filantropi islam, sejarah dan kontestasi masyarakat sipil dan Negara di Indonesia.

Hadi, A. H. (n.d.). Strategi Perlindungan Dan Pemberdayaan Anak Terlantar Melalui Program Rumah Belajar Anak Lembaga Kemanusiaan Aksi Cepat Tanggap (ACT).

Moh. Nazir. (2003). Metode Penelitian. Jakarta: PT Ghalia Indonesia.

Lubis Member of MRI-ACT Parepare Branch (personal communcation, 19 November 2019)

MRI. (n.d.). No Title. Retrieved from https://relawan.id/tentang-kami/

Rahmadi, Y. M., \& Syauqillah, M. (2019). The Humanitarian Assistence Role of Aksi Cepat Tanggap (ACT) Toward Victims of Syrian Conflict in Syria and Turkey From 2012 To 2018.

Ridwan, M. (2016). Analisis Model Fundraising dan Distribusi Dana ZIS di UPZ Desa Wonoketingal Karanganyar Demak. Jurnal Penelitian, 1O(2), 295-321.

Sabri, Member of MRI-ACT Parepare Branch (personal communcation, 19 November 2019)

Sofjan Assauri. (2013). Strategi Manajemen Sustainable Competitive (Cet.2). Jakarta: Rajawali Pers.

Syaifuddin Azwar. (2004). Metode Penelitian. Yogyakarta: Pustaka Belajar.

Tjiptono, F. (2008). Strategi Pemasaran Edisi 3. Yogyakarta: Andi.

Wahyuni, T. (2017). ANALISIS KOMPARATIF MANAJEMEN PENGELOLAAN DANA FILANTROPI BERBASIS RUMAH IBADAH DAN LEMBAGA SOSIAL DITINJAU DARI PERSPEKTIF EKONOMI ISLAM (Studi Pada Masjid Ad-Du'a Way Halim Bandar Lampung dan LAZNAS Dompet Peduli Ummat Daarut Tauhiid Cabang Metro). UIN Raden Intan Lampung. 